\title{
BROWN BEAR (URSUS ARCTOS L.) IN THE CHORNOBYL EXCLUSION ZONE
}

\author{
Sergii Gashchak ${ }^{1}$, Yevgenii Gulyaichenko ${ }^{1}$, Nicholas A. Beresford ${ }^{2,3}$, Michael D. Wood $^{3}$

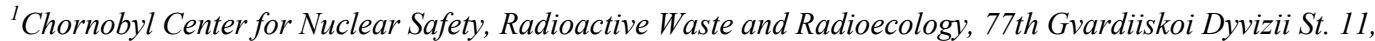 \\ Slavutych, Ukraine 07101, e-mail: sgaschak@chornobyl.net \\ ${ }^{2}$ NERC Center of Ecology \& Hydrology, Library Av., Bailrigg, Lancaster, LA1 4AP United Kingdom, \\ e-mail:nab@ceh.ac.uk \\ ${ }^{3}$ University of Salford, Peel Building, University of Salford, Salford, M5 4WT United Kingdom, \\ e-mail:M.D.Wood@salford.ac.uk
}

\begin{abstract}
Brown Bear (Ursus arctos L.) in the Chornobyl Exclusion Zone. - Gashchak, S., Gulyaichenko, Y., Beresford, N. A., Wood, M. D. - A study in 2012-2016 using camera traps confirmed the presence of brown bear in the Chornobyl exclusion zone (Ukraine). The presence of ca. 2-3 individuals was established in an area of up to $80 \mathrm{~km}^{2}$ near the village of Tovstyi Lis. Bears were observed on 17 occasions in all seasons except winter. Confirmed sightings were also recorded near the villages of Paryshiv and Ladyzhychi, though number of the animals in this area is unknown. Both locations include vast broadleaved woodlands with moist soil and abundant food reserves. The evidence collected (photographs, video, footprints, markings on trees, oral reports of a female bear with cubs) suggest the development of a resident breeding group and the revival of the species in Kyiv Polissia after centuries of its absence. This is facilitated by the size of the exclusion zone $\left(2,600 \mathrm{~km}^{2}\right)$, abundant resources and the absence of humans. A similar revival of bear has been reported in the neighbouring Poliskyi Radioecological Reserve in Belarus. Together both territories $\left(4,750 \mathrm{~km}^{2}\right)$ promise to be a new large reservation for brown bear in Eastern Europe.
\end{abstract}

Key words: Brown bear, Chornobyl exclusion zone, camera trap, revival of species, favourable habitats.

\begin{abstract}
Бурий ведмідь (Ursus arctos L.) у Чорнобильській зоні відчуження (Україна). - Гащак, С., Гуляйченко, Є., Бересфорд, Н. А., Вуд, М. Д. - Дослідження з фотопастками у 2012-2016 рр. довели наявність бурого ведмедя у Чорнобильській зоні відчуження (Україна). Близько 2-3 особин мешкає на ділянці до 80 км² біля с. Товстий ліс. Ведмедів реєстрували 17 разів у всі сезони, крім зими. Підтверджені спостереження також надійшли з району с. Паришів та Ладижичі, хоча кількість звірів там невідома. Обидві ділянки включають великі широколистяні ліси 3 добрим зволоженням грунтів і багатою кормовою базою. Зібрані свідчення (фотографії, відео, сліди, подряпини на деревах, усні повідомлення про ведмедицю з ведмежатами) вказують на розвиток місцевою групи, що розмножується, і відновлення виду у Київському Поліссі після століть відсутності. Цьому сприяє розмір зони відчуження $\left(2600 \mathrm{kм}^{2}\right)$, рясність ресурсів та відсутність людей. За літературними даними, подібне відновлення ведмедя відбувається у сусідньому Поліському радіоекологічному заповіднику Білорусії. Обидві території разом (4750 км²) обіцяють стати новим великим резерватом ведмедя у Східній Європі.

Ключові слова: ведмідь бурий, Чорнобильська зона відчуження, фотопастка, відновлення виду, сприятливі місця мешкання.
\end{abstract}

\section{Introduction}

A recent analysis of data on large carnivores in Europe demonstrated that the brown bear is the most numerous and in most areas there are no concerns with respect to the future of the species which appears to have stable or growing populations (Chapron et al., 2014). However, the situation is different in Ukraine: 40 years of observations demonstrated a reduction in brown bear numbers, with a distribution confined to areas in the Carpathian Mountains (Dykyy et al., 2015). This was caused by direct persecution by humans and deforestation. Currently, the brown bear is on the Red List (The Red Data Book of Ukraine, 2009) and preservation of the species is threatened by the prevailing socio-political and economic conditions in Ukraine. Therefore, any evidence of areas where brown bear numbers appear to be increasing warrants targeted research, and the Chornobyl exclusion zone (hereinafter referred to as the "CEZ") could be such an area. 
The CEZ is located in the northern part of the Kyiv region in Polissia, Ukraine. People have been excluded from this area since 1986 due to radioactive contamination from the Chernobyl accident. Since the accident, the primary focus of science programmes has been assessment of the CEZ in the context of mitigating the consequences of the accident and achieving radiation protection objectives. However, since the accident, ecological succession has underpinned the processes of rewilding, which is reviving the natural systems in Polissia that were lost or significantly changed during the previous centuries. Over the last 30 years, the Ukrainian CEZ (up to 260,000 ha or $2,600 \mathrm{~km}^{2}$ ) has experienced human activity on no more than $15 \%$ of the total area. In-effect, it has become, together with the Poliskyi Radiation \& Ecology Reserve (an exclusion zone in Belarus), a unique wildlife reserve of continental value (Gashchak, 2006).

The increased number of game and "Red List" species, as well as the recovery of species that had been excluded due to human activity is a demonstration of the development of favourable natural conditions (Gashchak et al., 2006). Recently, the bear was included into the list of "returnees", but data on this species were fragmentary and vague (Shkvyria, Vishnevsky, 2012; Dykyy et al., 2015). New and more complete data were obtained from 2012-2016, within the scope of two research programmes on CEZ biodiversity: (i) a 'national project' of the Ministry of Ecology and Natural Resources of Ukraine; and (ii) the international TREE project (http://tree.ceh.ac.uk).

The purpose of this paper is to present the accumulated data on brown bear in the CEZ and analyse them in terms of assessing the status and prospects of this species in the region.

\section{Methodology}

The data presented in this paper were mainly obtained by means of motion activated digital cameras ("camera traps") capable of capturing images during the day and night, using infrared sensors and invisible infrared flash. Since brown bear was not the primary focus of the CEZ biodiversity research programmes, the methodology of obtaining initial data varied. The aim of the "national project' camera trap work (undertaken between 2012 and 2016) was to comprehensively describe four sites within CEZ, each ca. 8,000 hectares in area (fig. 1, tab. 1). Additionally, seven camera traps were located at sites outside these main sampling areas. Camera traps were installed at 52 locations in total, delivering combined total survey duration of 7788 camera trap days.

The camera traps were located and oriented in positions where animals were likely to be encountered: mostly at the points where animals crossed water bodies (e.g. bridges over channels) or near well-marked pathways or their intersections. Preference was given to locations where movement of animals was channelled by natural barriers (e.g. by water or thickets).

Table 1. Main sites and additional points used for 'national project' CEZ camera trapping during 2012-2016

Таблиця 1. Основні ділянки та додаткові точки у зоні відчуження, де встановлювали фотопастки у національних проектах у 2012-2016 роках

\begin{tabular}{l|l|c|c|c|c}
\hline No. & Operating name of site & $\begin{array}{c}\text { ID on } \\
\text { fig. 1 }\end{array}$ & $\begin{array}{c}\text { Number of cam- } \\
\text { era trap locations }\end{array}$ & $\begin{array}{c}\text { Total operation time of } \\
\text { camera traps, days }\end{array}$ & $\begin{array}{c}\text { Period of camera trap } \\
\text { survey }\end{array}$ \\
\hline & Main sites & & & \\
1 & Tovstyi Lis & TL & 19 & 1589 & $05.2012-06.2013$ \\
2 & Novosilky & N & 5 & 491 & $04.2012-01.2013$ \\
3 & Horodyshche & H & 6 & 1641 & $06.2013-06.2014$ \\
4 & Buda-Richytsia Meadows & DR & 16 & 2207 & $06.2014-11.2016$ \\
& Additional points & & & & \\
5 & Azbuchyn Lake & AL & 1 & 152 & $10.2015-03.2016$ \\
6 & Akulino Halo Stow & AH & 1 & 313 & $06.2015-10.2016$ \\
7 & Denysovichi Village & DV & 1 & 200 & $11.2015-10.2016$ \\
8 & Stupnikove Stow & ST & 1 & 542 & $07.2014-10.2015$ \\
9 & Rozhava River & RO & 1 & 395 & $04.2015-04.2016$ \\
10 & Chornyi Mokh Stow & CM & 1 & 259 & $06.2015-02.2016$ \\
\hline
\end{tabular}




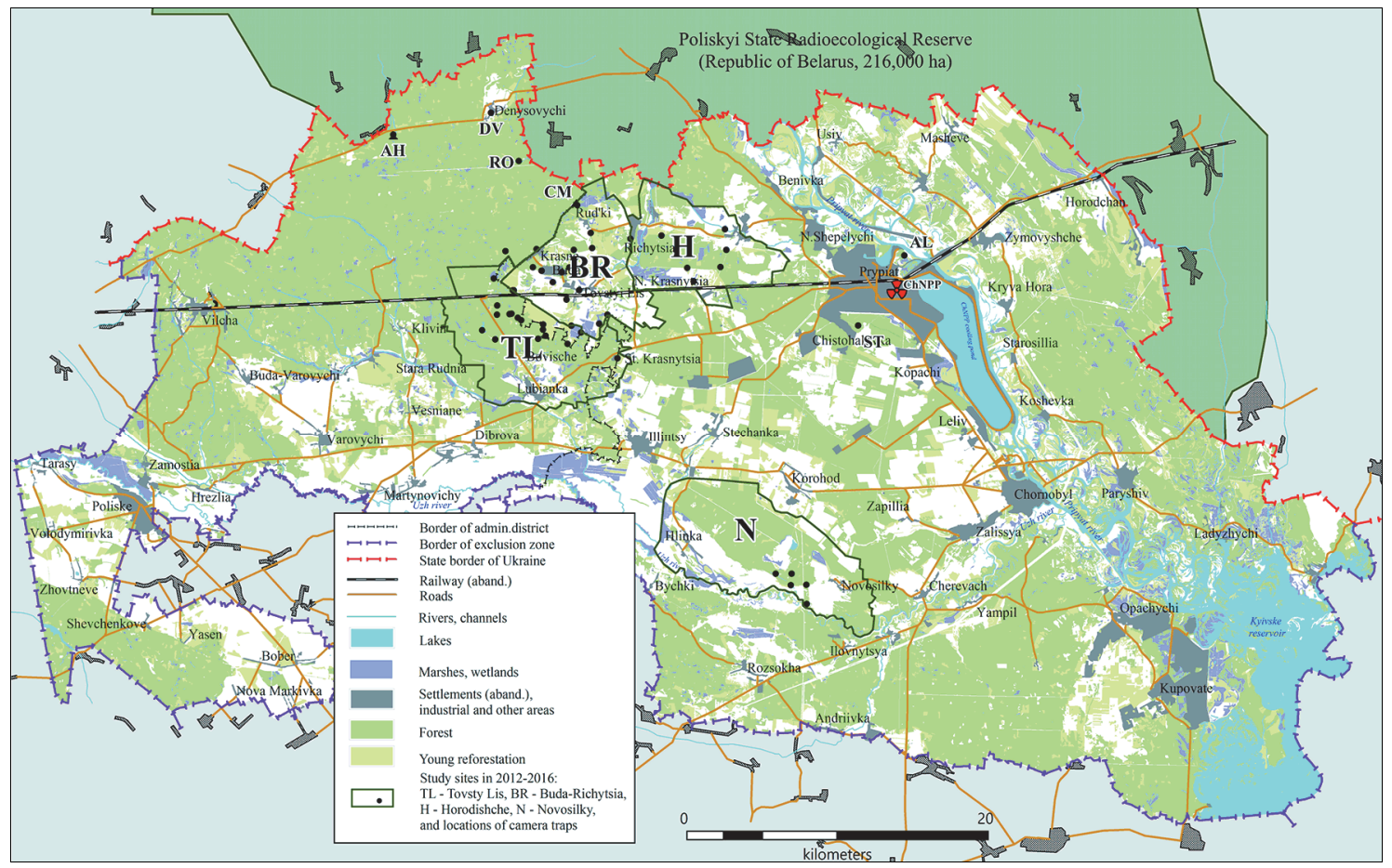

Fig. 1. Locations of 'national project' study sites in 2012-2016 (ID of sites and points as in tab. 1).

Рис. 1. Розташування дослідних ділянок в рамках національних проектів у 2012-2016 роках (позначки ділянок і точок, як у табл. 1).

Bait was not used in the study. The cameras were placed on trees or specially made poles at a height of $0.6-1.0 \mathrm{~m}$ above the ground and at a distance of 3-8 m from the main trails. To prevent false activations caused by sunlight, the cameras mostly faced north or towards thickets to shield from direct sunlight. Given that the cameras are motion-activated, tall grass, bushes and thin tree branches were removed from the detection zone in front of the cameras again to prevent false activation. As a rule, cameras were oriented parallel to the ground, but the exact orientation depended on local topography, camera height and trail location.

Camera traps from different manufacturers, including Ltl Acorn 5210A, Ltl Acorn 6210MC, Bushnell 119437c, DLC Covert Red 40, Weltar 8210A and Browning Strike Force, were used. All these cameras use an infrared flash $(850$ or $940 \mathrm{~nm})$ that is hardly visible at night, but in our experience appears to provide sufficient illumination for objects up to 10 meters from the camera. Despite some differences in their technical specifications, they demonstrated similar shooting performance for large animals at a distance of 6-8 meters. A HCO Scoutguard $880 \mathrm{MK}$ camera was used only at points 5 and 8 (tab. 1). Compared to the other cameras, this camera seemed less responsive to animal movement. The sensitivity settings of all cameras were varied depending on the season and characteristics of shooting locations (real distance to the trail, direction, how far and what vegetation was in front of the camera, etc.). In each case, a three picture burst per triggering event and a minimum operation delay of 0 or 1 seconds were pre-set; the exception was the Browning Strike Force which had a default delay of 5 seconds. However, the time delay between photograph capture and camera readiness for another shooting cycle was relatively long: 3-4 seconds for Bushnell $119437 \mathrm{c}$, Ltl Acorn and Weltar 8210A, 5-10 seconds for Covert Red 40, HCO Scoutguard 880MK and Browning Strike Force. Therefore, it is possible that some animals moving in front of a camera may not have been photographed (though this is unlikely to be an issue for the species considered in this paper).

The work within the framework of the TREE project was entirely based on the use of camera traps; Ltl Acorn $6210 \mathrm{MC}$ were used. For a period of approximately $8-9$ weeks, 14 camera traps were located on each of three sites in the CEZ (i.e. a total of 42 cameras across all three sites). 
Each site had a $5 \mathrm{~km}$ radius (fig. 2, tab. 2). The approximate camera trap location coordinates within each of the three sites were determined using a random number algorithm. In-situ, the exact location was chosen within a radius of 200-300 meters from the randomly-generated coordinate position. The location selection principles, methodology of vegetation clearing in front of the camera, deployment and camera setup procedures were similar to those used for the 'national project'. After the 8-9 week period, all cameras were moved to new randomly generated coordinates within each site. There were six relocations in total (i.e. each camera was used in seven locations) over the period November 2014 to January 2016. Subsequent to this study ending four cameras continued to be operated in each of the three areas for a further six months.

It should be noted that the TREE project's West Site coincided with the "Buda-Richytsia Meadows" site of the national project, and the South Site comprised a considerable part of the "Novosilky" Site. This enables suggestions about some temporal and spatial trends.

When setting up each camera trap, up to 20 measuring poles $(1 \mathrm{~m}$ high and with clear markings at every $20 \mathrm{~cm}$ ) were laid out in front of the camera. The poles were placed in three parallel rows, at a distance of 1 meter, starting with the $3^{\text {rd }}$ meter and up to the $8^{\text {th }}$ from a camera trap. The camera was activated to capture an image of the poles in situ and the bars were then removed. Later, images of poles and animals were overlaid using Adobe Photoshop so that animal dimensions could be estimated.

Table 2. Basic characteristics of research sites used within the TREE project

Таблиця 2. Основні характеристики дослідних ділянок в рамках проекту TREE

\begin{tabular}{l|l|c|c|c}
\hline No. & $\begin{array}{l}\text { Operating name } \\
\text { of site }\end{array}$ & $\begin{array}{c}\text { Total number of camera } \\
\text { trap locations }\end{array}$ & $\begin{array}{c}\text { Total operation time } \\
\text { of camera traps (days) }\end{array}$ & Period of camera trap survey \\
\hline 1 & North & 95 & 6205 & $11.2014-06.2016$ \\
2 & West & 97 & 6485 & $11.2014-06.2016$ \\
3 & South & 96 & 6185 & $11.2014-06.2016$ \\
\hline
\end{tabular}

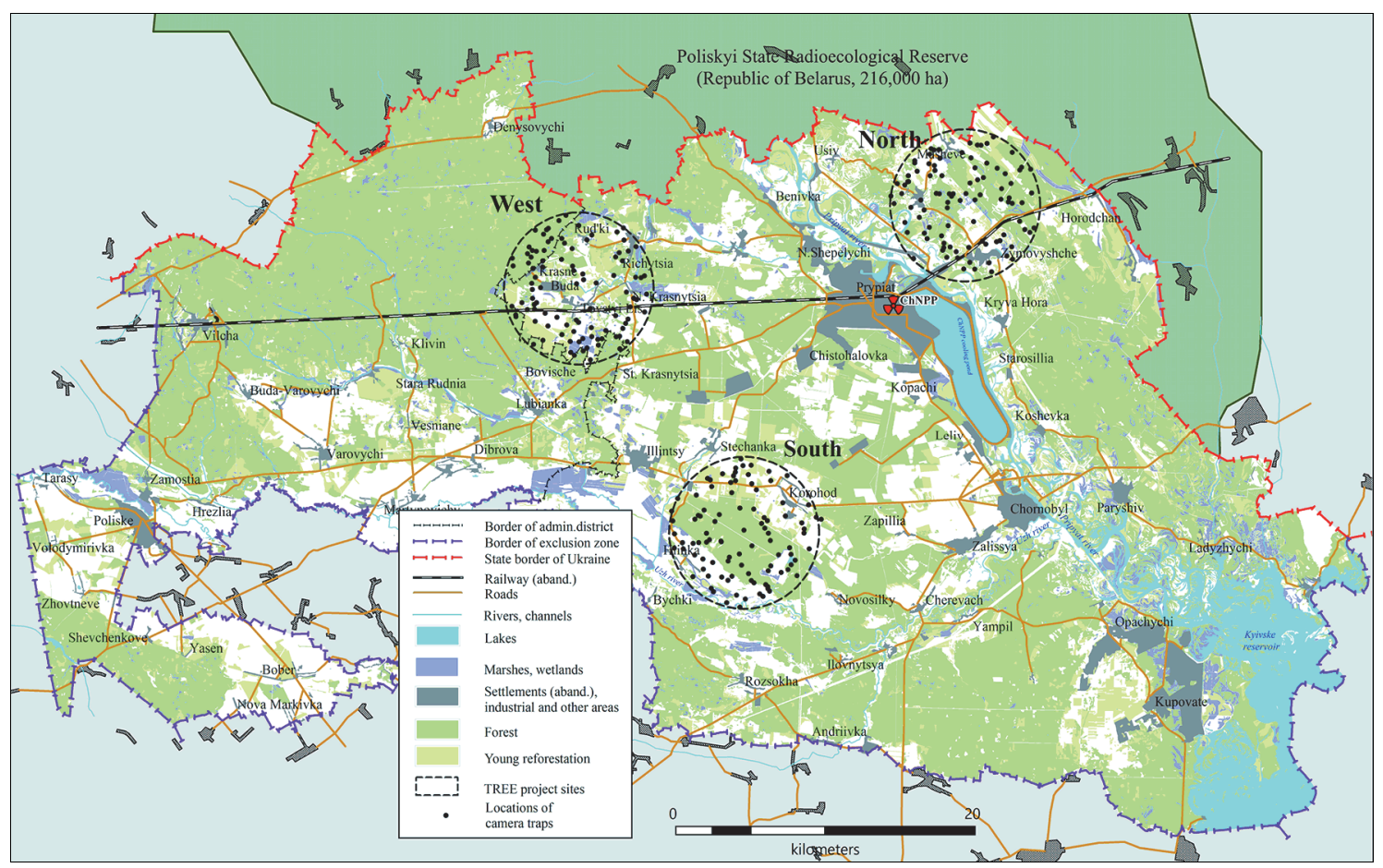

Fig. 2. Location of research sites used within the TREE project.

Рис. 2. Розташування дослідних ділянок в рамках проекту TREE. 
The time during which a bear was recorded near a camera trap (one event) was calculated as the difference between the time of the first and the last pictures associated with that event.

This paper also includes information, which is based on the video footage kindly provided by Oleksandr A. Nikitych, employee of the "Ecocenter" enterprise; on oral reports of Vasyl A. Davydenko, Chief Game Manager of "Pivnichna Pushcha" enterprise, and Sergii A. Paskevych, employee of the NPP Safety Support Institute.

Officially accepted forest management layout of 2006 (Development Project, 2006) was used to assess forest conditions at the camera trap sites.

\section{Results}

The locations of camera traps that recorded bears are shown in fig. 3 and the details of each event are presented in table 3. Although the camera traps were operated from 2012 onwards and at several sites within CEZ, all photographs of bear were obtained from October 2014 onwards at "Buda-Richytsia Meadows" and "Tovstyi Lis" only. There was no evidence of bear presence within the North and South sites used for the TREE project even though there was a similar number of camera placements in all three TREE project areas. Coordinates of the camera traps locations are reported in Longitude/Latitude (WGS84 system).

We obtained 17 observations of bear within an area of $5 \mathrm{~km}$ radius around the village of Tovstyi Lis. All observations were from October 2014 to October 2016, in May-June and August to early November. Nine out of 17 observations occurred at night-time, one was at dawn. Although bears appeared in daylight hours on 7 occasions, these were either in the first hours after sunrise or before sunset. These observations of seasonal and daily activity are in agreement with the known ecological characteristics of this species: brown bears mainly roam at dusk or during the night and usually rests or feed during the daytime (Heptner et al., 1967; Pazhetnov, 1990; Dykyy et al., 2015).

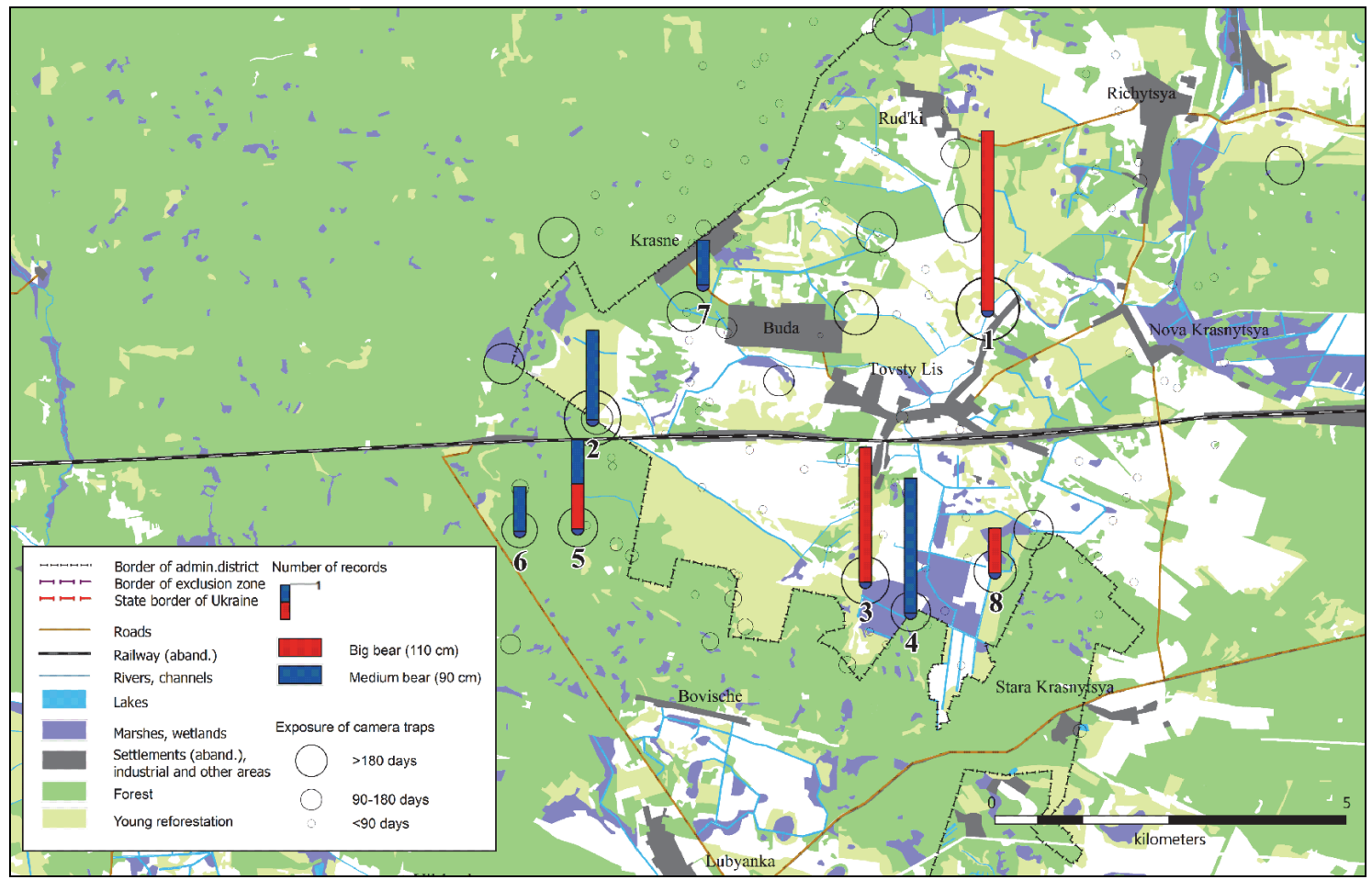

Fig. 3. Locations of bear observations in 2014-2016. Numerical symbols near points correspond to point's number in tab. 3 .

Рис. 3. Розташування місць реєстрації ведмедя у 2014-2016 роках. Цифри біля точок відповідають номерам точок у табл. 3. 
Table 3. List of records of brown bear made by camera traps in the CEZ during 2014-2016 ('point numbers' in the site description correspond to the points shown in fig. 3)

Таблиця 3. Перелік випадків реєстрації бурого ведмедя зроблені фотопастками у зоні відчуження у 2014-2016 роках (номери точок в описах ділянки відповідають номерам точок на рис. 3)

\begin{tabular}{|c|c|c|c|}
\hline $\begin{array}{l}\text { Record } \\
\text { No. }\end{array}$ & Description of site (coordinates) & $\begin{array}{l}\text { Date and } \\
\text { time }\end{array}$ & Description of animal \\
\hline 1.1 & \multirow{4}{*}{$\begin{array}{l}\text { Point No. } 1 \text { (N51.3967, E29.8112). } \\
\text { Bridge over channel on the edge } \\
\text { of abandoned village }\end{array}$} & $\begin{array}{c}2.10 .2014 \\
20: 22 \text { (night) }\end{array}$ & $\begin{array}{l}\text { Shoulder height }-\mathrm{ca} .110 \mathrm{~cm} \text {, length of rear foot } \\
-30-33 \mathrm{~cm} \text {, stayed near the camera up to } 45 \mathrm{sec} \text {. } \\
\text { Appeared to be moving northward. }\end{array}$ \\
\hline 1.2 & & $\begin{array}{l}26.08 .2015 \\
3: 16 \text { (night) }\end{array}$ & $\begin{array}{l}\text { Shoulder height - ca. } 105 \mathrm{~cm} \text {, rear foot - at least } \\
25 \mathrm{~cm} \text {. Appeared to be moving northward. Passed } \\
\text { the camera over } 3 \mathrm{sec} \text {. }\end{array}$ \\
\hline 1.3 & & $\begin{array}{l}9.10 .2015 \\
3: 25 \text { (night) }\end{array}$ & $\begin{array}{l}\text { Shoulder height - ca. } 105 \mathrm{~cm} \text {. Appeared to be } \\
\text { moving northward. Passed the camera over } 2 \mathrm{sec} \text {. }\end{array}$ \\
\hline 1.4 & & $\begin{array}{l}27.08 .2016 \\
2: 23 \text { (night) }\end{array}$ & $\begin{array}{l}\text { Shoulder height - ca. } 110 \mathrm{~cm} \text {, rear foot - } \\
\text { ca. } 33 \mathrm{~cm} \text {. Appeared to be moving northward. } \\
\text { Passed the camera over } 2 \mathrm{sec} .\end{array}$ \\
\hline 2.1 & \multirow{2}{*}{$\begin{array}{l}\text { Point No. } 2 \text { (N51.3806, E29.7320). } \\
\text { Passage across channel on the edge } \\
\text { of a large forest, where broad-leaved } \\
\text { trees predominate }\end{array}$} & $\begin{array}{l}31.08 .2015 \\
6: 54 \text { (day) }\end{array}$ & $\begin{array}{l}\text { Shoulder height - 90-93 cm, rear foot - } \\
\text { ca. } 25 \mathrm{~cm} \text {. Appeared to be moving north-east, } \\
\text { passed the camera over } 3 \mathrm{sec} \text {. (Fig. } 4 \text { ) }\end{array}$ \\
\hline 2.2 & & $\begin{array}{c}30.08 .2016 \\
21: 57 \text { (night) }\end{array}$ & $\begin{array}{l}\text { Shoulder height - ca. } 95 \mathrm{~cm} \text {. Probably noticed a } \\
\text { camera flash, stayed for } 35 \mathrm{sec} \text { but did not come up } \\
\text { to the camera, and turned back }\end{array}$ \\
\hline 3.1 & \multirow{3}{*}{$\begin{array}{l}\text { Point No. } 3 \text { (N51.3615, E29.7896). } \\
\text { Bridge over channel in the middle } \\
\text { of a former meadow overgrown } \\
\text { with birch }\end{array}$} & $\begin{array}{c}25.08 .2015 \\
5: 14 \text { (day) }\end{array}$ & $\begin{array}{l}\text { Stayed near camera ca. } 16 \mathrm{sec} \text { and looked at it. } \\
\text { Back height - ca. } 110 \mathrm{~cm} \text {. Appeared to be moving } \\
\text { southward. }\end{array}$ \\
\hline 3.2 & & $\begin{array}{l}8.10 .2015 \\
2: 44 \text { (night) }\end{array}$ & $\begin{array}{l}\text { Shoulder height - ca. } 110 \mathrm{~cm} \text {. Appeared to be } \\
\text { moving northward. Passed the camera over } 9 \mathrm{sec} \text {. }\end{array}$ \\
\hline 3.3 & & $\begin{array}{c}12.10 .2016 \\
22: 30 \text { (night) }\end{array}$ & $\begin{array}{l}\text { Shoulder height - ca. } 110 \mathrm{~cm} \text {, rear foot - } \\
\text { ca. } 30 \mathrm{~cm} \text {. Appeared to be moving northward. } \\
\text { Passed the camera over } 4 \mathrm{sec} .\end{array}$ \\
\hline 4.1 & \multirow{3}{*}{$\begin{array}{l}\text { Point No. } 4 \text { (N51.3576, E29.7984). } \\
\text { Passage across channel on the edge } \\
\text { of old hornbeam-oak forest }\end{array}$} & $\begin{array}{l}17.08 .2016 \\
5: 49 \text { (day) }\end{array}$ & $\begin{array}{l}\text { Shoulder height - ca. } 95 \mathrm{~cm} \text {, rear foot - } \\
\text { ca. } 20 \mathrm{~cm} \text {. Appeared to be moving westward. } \\
\text { Passed the camera over } 4 \mathrm{sec} .\end{array}$ \\
\hline 4.2 & & $\begin{array}{l}17.08 .2016 \\
7: 18 \text { (day) }\end{array}$ & $\begin{array}{l}\text { Shoulder height - ca. } 90 \mathrm{~cm} \text {, rear foot - } \\
\text { ca. } 20 \mathrm{~cm} \text {. Appeared to be moving westward. } \\
\text { Passed the camera over } 6 \mathrm{sec} .\end{array}$ \\
\hline 4.3 & & $\begin{array}{c}21.09 .2016 \\
20: 37 \text { (night) }\end{array}$ & $\begin{array}{l}\text { Shoulder height }-88-90 \mathrm{~cm} \text {, rear foot - } \\
\text { ca. } 23 \mathrm{~cm} \text {. Appeared to be moving eastward, to- } \\
\text { wards the forest. Passed the camera over } 48 \mathrm{sec} \\
\text { (ate or sniffed something on the ground). }\end{array}$ \\
\hline 5.1 & $\begin{array}{l}\text { Point No. } 5 \text { (N51.3663, E29.7300). } \\
\text { Crossing of forest tracks in the } \\
\text { middle of old forest where broad- }\end{array}$ & $\begin{array}{c}20.05 .2016 \\
3: 24 \\
(\text { dawn })\end{array}$ & $\begin{array}{l}\text { Shoulder height - ca. } 105 \mathrm{~cm} \text {. Appeared to be } \\
\text { moving eastward. Passed the camera over } 2 \mathrm{sec} .\end{array}$ \\
\hline 5.2 & $\begin{array}{l}\text { leaved trees predominate, near the } \\
\text { tree with a bear's claw mark }\end{array}$ & $\begin{array}{l}1.06 .2016 \\
8: 47 \text { (day) }\end{array}$ & $\begin{array}{l}\text { Shoulder height }- \text { ca. } 90-95 \mathrm{~cm} \text {. Appeared to be } \\
\text { moving north-west. Passed the camera over } 2 \mathrm{sec} \text {. }\end{array}$ \\
\hline 6.1 & $\begin{array}{l}\text { Point No. } 6 \text { (N51.3656, E29.7176). } \\
\text { Crossing of swathe and track in old } \\
\text { hornbeam-oak forest }\end{array}$ & $\begin{array}{l}28.05 .2016 \\
19: 00 \text { (day) }\end{array}$ & $\begin{array}{l}\text { Shoulder height }-90 \mathrm{~cm} \text {. Appeared to be moving } \\
\text { northward. Passed the camera over } 3 \mathrm{sec} \text {. }\end{array}$ \\
\hline 7.1 & $\begin{array}{l}\text { Point No. } 7 \text { (N51.3981, E29.7529). } \\
\text { Pathway between villages in woody } \\
\text { shrubs (birch, aspen) }\end{array}$ & $\begin{array}{l}4.11 .2015 \\
21: 49 \\
\text { (night) }\end{array}$ & $\begin{array}{l}\text { Shoulder height }-90-95 \mathrm{~cm} \text {. Appeared to be } \\
\text { moving north-west. Passed the camera over } 4 \mathrm{sec} \text {. }\end{array}$ \\
\hline 8.1 & $\begin{array}{l}\text { Point No. } 8 \text { (N51.3631, E29.8150). } \\
\text { Bridge over channel in the middle } \\
\text { of a meadow overgrown with birch }\end{array}$ & $\begin{array}{l}26.08 .2016 \\
4: 39 \text { (day) }\end{array}$ & $\begin{array}{l}\text { Shoulder height - up to } 110 \mathrm{~cm} \text {. Rear foot - up } \\
\text { to } 27 \mathrm{~cm} \text { long. Appeared to be moving eastward. } \\
\text { Passed the camera over } 10 \mathrm{sec} .\end{array}$ \\
\hline
\end{tabular}




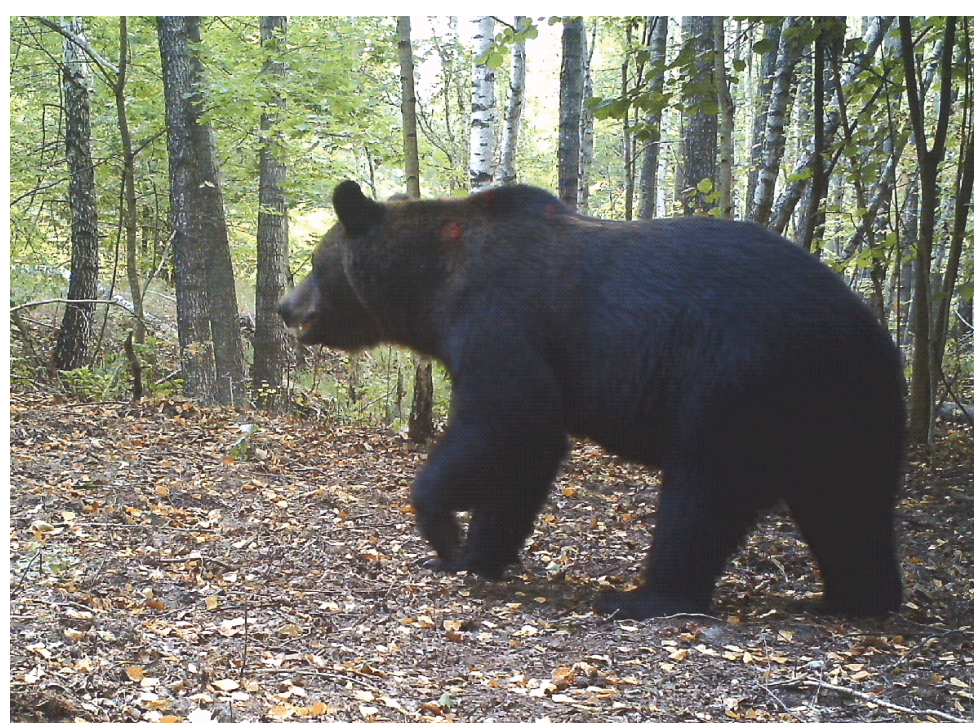

Fig. 4. Brown bear (record 2.1 in tab. 3).

Рис. 4. Бурий ведмідь (запис 2.1 в табл. 3).

The lack of bear observations from December to April coincides with period during which bears are generally confined to their dens, although true hibernation can be short or absent under the conditions of the climatic zone that the CEZ falls within (Dykyy et al., 2015). For example, in the neighbouring Poliskyi State Radioecological Reserve, there have been some winter observations of bear (Deriabina, 2008). The lack of observations from July may be because the bears were at their preferred feeding sites and these may not have coincided with the locations of camera traps. More settled behaviour in periods of food abundance is typical for this species (Pazhetnov, 1990)

Overlaying measurement pole images, as described in the methodology section, allowed animals of two different size-groups to be identified. The first one had a shoulder height of ca. 105$110 \mathrm{~cm}$ with a rear foot size at least $30 \mathrm{~cm}$. Height of animals in the second size-group did not exceed 90-95 cm, and their rear foot was 20-23 cm. The data obtained do not allow comment on the number of animals on this territory. Bears are usually solitary but they can co-exist in the same area avoiding direct contact (Pazhetnov, 1990). With respect to the smaller animals, on August 17, 2016 a camera trap at one location recorded a bear on two occasions within a period of 1.5 hours (records 4.1 and 4.2, tab. 3). On both occasions the animals were moving in the same direction and the dimensions of the animals suggest that these could be two different individuals.

Analysis of the locations where individuals of different size were recorded suggests that they are unevenly distributed across the area. The large animal (or animals) of up to $110 \mathrm{~cm}$ shoulder height was more frequently recorded far from uninterrupted woodlands; while the smaller ones (up to $90-95 \mathrm{~cm}$ ) were registered either within forest areas or near the forest edge. This distribution may reflect behavioural differences of adult males and other individuals of the population, with males being less cautious and more active (Dykyy et al., 2015). On this basis, it is likely that the largest bears recorded are males, but there is no reliable way to determine gender definitively from the camera trap images.

Two records (8.1 and 1.4 in tab. 3) may indicate that the same large animal moved from one point to another over a distance of $4.2 \mathrm{~km}$ in a period of 22 hours. If we assume that only one large specimen lives in this area, then this bear passed the same point (No. 1, in the north of Tovstyi Lis village, tab. 3) four times over the three years (records 1.1-1.4 in tab. 3), always moving in the same direction, which indicates some constancy of its route when roaming in the area.

Based on the photographs obtained to date, the bears showed little interest in the camera traps. There were two exceptions: one animal $(110 \mathrm{~cm})$ stayed near a camera for approximately 16 seconds and looked at the camera directly (record 3.1 in tab. 3); and another animal $(90 \mathrm{~cm}$ ) appears to have noticed the infrared flash at night and decided to move away from the camera as a result (record 2.2 in tab. 3). 


\section{Discussion}

\section{Origin of Chornobyl's brown bears}

The appearance of brown bear in the exclusion zone is + unsurprising, it was native to the region in the past and there are established resident populations within a few hundred kilometres. The species used to live in Polissia and also further south, in vast territories of forest-steppe and steppe zones (Heptner et al., 1967). However, its population dramatically decreased in the $17^{\text {th }}-19^{\text {th }}$ centuries due to persecution by humans, deforestation and depletion of food resources. Brown bear had disappeared from Kyiv Polissia by the late $19^{\text {th }}$ century (Kirikov, 1960, 1979; Sokur, 1961) and by the mid-twentieth century its distribution was restricted to areas with minimal human disturbance, far to the west and north of the present day CEZ.

Although bears have long been resident in the Ukrainian Carpathians (500-600 km from the CEZ), there are areas closer to the CEZ which historically had established brown bear populations: Belarus (400-500 km from the CEZ) and Russia (250-300 km from the CEZ). For example, up to 50-80 individuals were counted in the Vitebsk region of Belarus before the 1980s (Savitsky et al., 2005) and 30-40 individuals were estimated for the Briansk region of Russia before the 1960s (Heptner et al., 1967). More recently, in 1980-1990s, up to 110-130 individuals were thought to be resident in Belarus and bear were observed with increasing frequency in more southern regions of the country, including the Belarusian part of the exclusion zone (Savitsky et al., 2005; Deriabina, 2008). In the 1990s, a few dozen bear cubs were released into the Briansk region of Russia (Sitnikova, 2004). There have been occasional reports of brown bear in some northern areas of Ukraine and it is likely that these are individuals from Belarus or Russia (Heptner et al., 1967; Kryzhanivskyi, 1999; Zhyla, 1997; The Red Data Book of Ukraine, 2009; Dykyy et al., 2015). Likewise, it is reasonable to assume that the bears observed in the CEZ are also from one of these areas.

The movement of brown bear into northern Ukraine has likely been facilitated by the reduction in rural population density and a decline in agricultural and forestry activities in vast areas of Polissia resulting from social and economic problems of the late $20^{\text {th }}$ - early $21^{\text {st }}$ centuries, including as a consequence of the Chornobyl accident. Therefore, the direct human pressure on both bears and their habitat has significantly decreased.

From, this perspective, conditions are favourable for a revival of brown bear within the CEZ. Bears are historically native to the area, the habitat is suitable, food sources are abundant and there is minimal human disturbance. Together with Poliskyi State Radiation and Ecological Reserve in Belarus, the area abandoned after the Chernobyl accident covers up to $4,750 \mathrm{~km}^{2}$ and is able to accommodate the relatively large home ranges of bears.

\section{Oral reports and evidences of brown bear in CEZ since 1990s}

The presence of brown bear in the CEZ was first suggested in 1993, long before the use of camera traps in the area. These oral reports from employees of local enterprises were difficult to verify, but suggested bear activity in forest area of the CEZ in the north-west near the villages of Vilcha, Denysovychi, Lubianka and Kovshylivka. There were also reports of observations near the villages of Opachychi and Koshevka. In the early 2000s, the frequency of unverified observation increased. The first bear footprints, which were verified by the authors of this paper, were observed in June 2003. The footprints were found in a fire break, near the village of Korohod. These $14 \times 24$ and $17 \times 33 \mathrm{~cm}$ footprints included feet pads and five toes with claws, which were typical of the species; the form and size of fore and rear feet were different.

The next time that researchers recorded signs of bear was in summer of 2009, in the form of marking scratches on an old spruce tree at the abandoned Tovstyi Lis Forestry base (Shkvyria, Vishnevsky, 2012). Several unverified oral reports were received in 2009-2011 from different parts of CEZ (Dykyy et al., 2015). In 2015, we also found an old spruce with bear scratches, just $700 \mathrm{~m}$ to the north-west of the Tovstyi Lis Forestry base. The scratches were at a height of 1.8-1.9 m (fig. 5). In 2016, camera trap recorded bear on two occasions at this location (records 5.1 and 5.2 in tab. 3). 

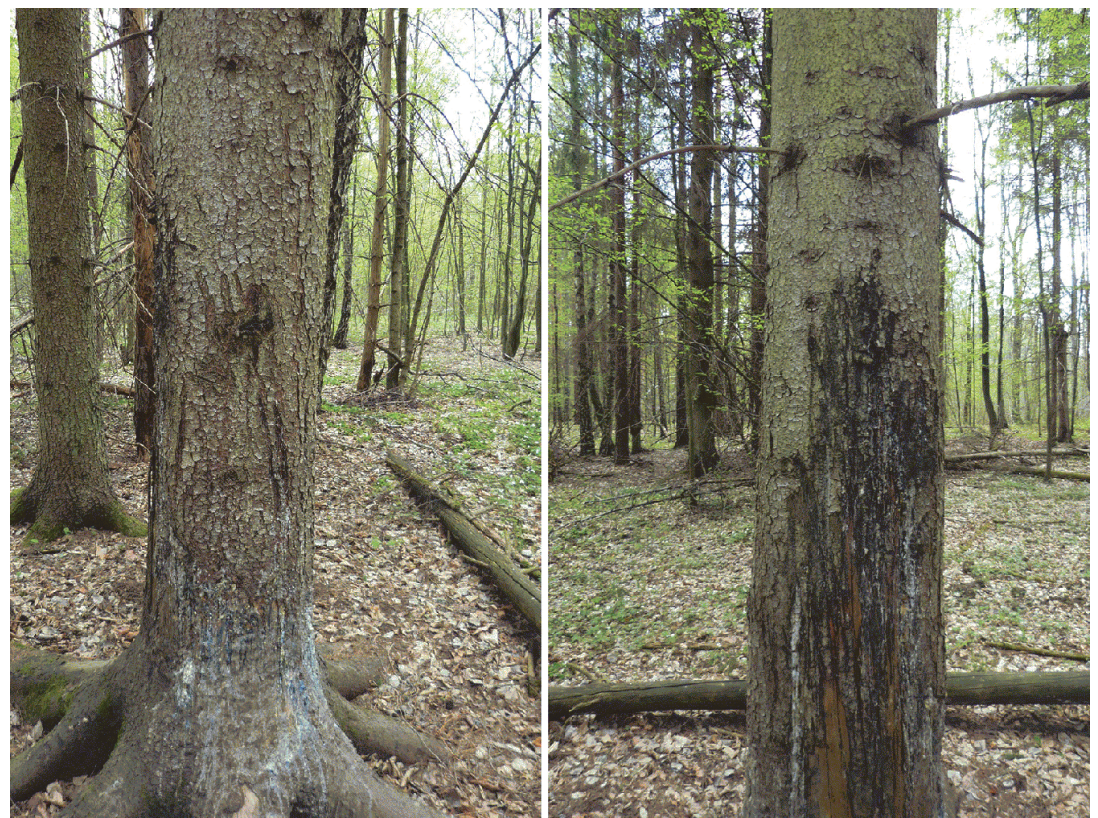

Fig. 5. Bear scratches on a tree found at the study site in 2015 .

Рис. 5. Ведмежі подряпини на дереві, знайдені на дослідній ділянці у 2015 р.

In addition to camera-records of bear, oral reports continued to be received of bear observations in other areas of the CEZ. For example, in summer 2015 huntsmen of the "Pivnichna Pushcha" Special Enterprise took photographs of footprints up to $30 \mathrm{~cm}$ long near the village of Ladyzhychi (oral report by V. A. Davydenko) in the south-east of the CEZ. In the same area, but inside the abandoned village, people reported seeing a female bear with two cubs in October 2015 (oral report of S. A. Paskevych after talking to eyewitnesses). In October 2015, 'illegal tourists' observed a bear near Cherevach (oral report of S. A. Paskevych after talking to eyewitnesses). One report, from O. A. Nikitych, was also accompanied by a digital video recording: at about 5 p.m. on July 02,2016 , a medium-sized bear was filmed on the road, $2 \mathrm{~km}$ north-east from the village of Paryshiv.

\section{Brown bear in the neighbouring reserve of Belarus}

Reports of brown bear in the Ukrainian CEZ were synchronous with similar reports from the neighbouring Poliskyi State Radiation \& Ecological Reserve of Belarus (Deriabina, 2008, 2011). According to Deriabina, a bear appeared there as early as 1992 and there were up to 70 recordings of bear (both footprints and the animals themselves) between 2003 and 2010. The earliest observations were mainly related to the sites on the right bank of the Prypiat River, directly adjacent to the CEZ. Later observations were mostly from the left bank, where scientists worked more often. In total, up to 4-5 adult bears were identified in the Poliskyi State Radiation \& Ecological Reserve by 2009. These adult bears are thought to include at least two large males and one female. Deriabina (2011) suggests that the status of bear within the Poliskyi State Radiation \& Ecological Reserve of Belarus has changed from temporary to permanent. There are several observations that led to this conclusion: (i) animals began to mark trees; (ii) females with cubs were observed in May 2007 and May 2009; and (iii) permanent localities of bears were found in the reserve near the villages of Orevychi, Borshchivka and Mykhailovka.

\section{Population size and distribution}

There are insufficient data to date to quantify the size of the brown bear population within the CEZ or comment on the gender and age structure of this population. Likewise, it is not yet possible to categorically state whether the bears are permanently resident within the CEZ or come over from Belarus (camera recordings have generally been relatively close to the border with Belarus). However, it is clear that the numbers of bear within the CEZ are low and that the species is unevenly distributed. Apparently, up to 2-3 animals regularly use the area near to the village of Tovstyi Lis 
for at least part of the year, but no bears were registered on the left (eastern) bank of Prypiat river, near the villages of Krasne and Masheve. However, 5-7 km to the north from the Krasne and Masheve, there are some sites in Belarus where bears are regularly observed (Deriabina, 2008). In spite of long-term observations there are no records of brown bear near the villages of Novosilky, Hlinka, Stari Shepelychi and Buriakivka. The only additional location where presence of the species has been proved is the south-east part of the CEZ, near the villages Paryshiv and Ladyzhychi.

\section{Prospects of brown bear revival in the CEZ}

The relatively frequent observations of bears near Tovstyi Lis in the west and near ParyshivLadyzhychi in the south-east may be related to habitat characteristics. For example, when assessing the brown bear distribution in the Carpathians, researchers (Dykyy et al., 2015) compared frequency of the records with a type of edaphotope (complex conditions created by soil in the given ecotope (Pohrebniak, 1955)). It turned out that the bear prefers hygrophilous habitats with rich nutrient content. Mesotrophic (C4) habitats accounted for $46 \%$ of bear observations and $23 \%$ of observations were from eutrophic (D4) habitats. The percentage of observations attributable to other hygrophilous habitats were: mesooligotrophic hygrophilous (B4) - $11.5 \%$, ultrahygrophilous (B5) $-9.2 \%$, and mesohygrophilous (B3) $-4.6 \%$, and oligotrophic hygrophilous (A4) $-2.3 \%$, and ultrahygrophilous (A5) - 3.4\%. There were no observations of brown bear in other types of edaphic conditions. Although the report does not describe general composition and distribution of edaphotopes, the bears clearly prefer those which have a good stock of vegetative foods even in dry seasons. Much of the CEZ has relatively poor soils with unstable water conditions (Petrov, 2016), so it is reasonable to assume that bears will favour richer mesotrophic and eutrophic habitats. Although landscapes and plant species structure in the Carpathian forests and in Kyiv Polissia differ significantly, the soil conditions (moisture and nutrient content) should play a key role in the CEZ as well.

According to the layout of forest management in the CEZ (Development Project, 2006), hygrotopes with moderate to good mineral supply (B3, B4, C3, C4, D3, D4) occupy only approximately $35 \%$ of the total area; and in the forests they are related to oak, hornbeam, alder, aspen, poplar and willow. The bear observations were restricted to areas where these species are the most numerous (fig. 6). The lands to the west and north-west of Tovstyi Lis village are notable for their hornbeamoak forests the largest in the CEZ, and numerous marshes and small damp meadows with rich forage (Petrov, Gashchak, 2013). Periodic yield of acorns, numerous berries (blackberry, blueberry, clusterberry, raspberry, strawberry, dewberry, stone brambleberry and cranberry), and a variety of grasses can provide a sustained food source for brown bear. Wild garlic (Allium ursinum L.), an important item of food in spring, is also found in this area. The local forests are characterized by many fallen trees, providing a reliable source of insect larva. A substantial addition to the diet may be consumption of ungulates (wild boar, red deer, elk, roe deer), which are common and whose numbers have increased markedly in recent decades (Gashchak et al., 2006). Abandoned villages are attractive to ungulates and carnivores in all seasons due to their rich soil and higher diversity of plants (Petrov, 2016). Similar conditions with an abundance of oak and sufficiently high soil moisture exist in the south-eastern part of CEZ, near the villages of Paryshiv and Ladyzhychi (fig. 6).

It is likely that the lack of bear observations in other areas with suitable habitat characteristics is due to lack of targeted research with automatic cameras in these areas.

Food availability is not the only favourable factor influencing bear revival in the region. Due to a long-term absence of forest management activities, many areas abound with fallen trees. Since such trees are often used for making dens (Heptner et al., 1967; Pazhetnov, 1990) the CEZ provides a wide selection of places suitable for dens. The site westward the village of Tovsty Lis where brown bear have been recorded in 2014-2016 has several locations with an abundance of fallen trees: first of all, mature hornbeam-oak and aspen forest in quarters 228-230, 250-252, 277 of the Lubianske Forestry Division (fig. 7 and 8).

When assessing the capacity of the CEZ to maintain a stable population of brown bears, it is useful to refer to the estimations of bear density in the localities closest to the CEZ where bear have been permanently present. 


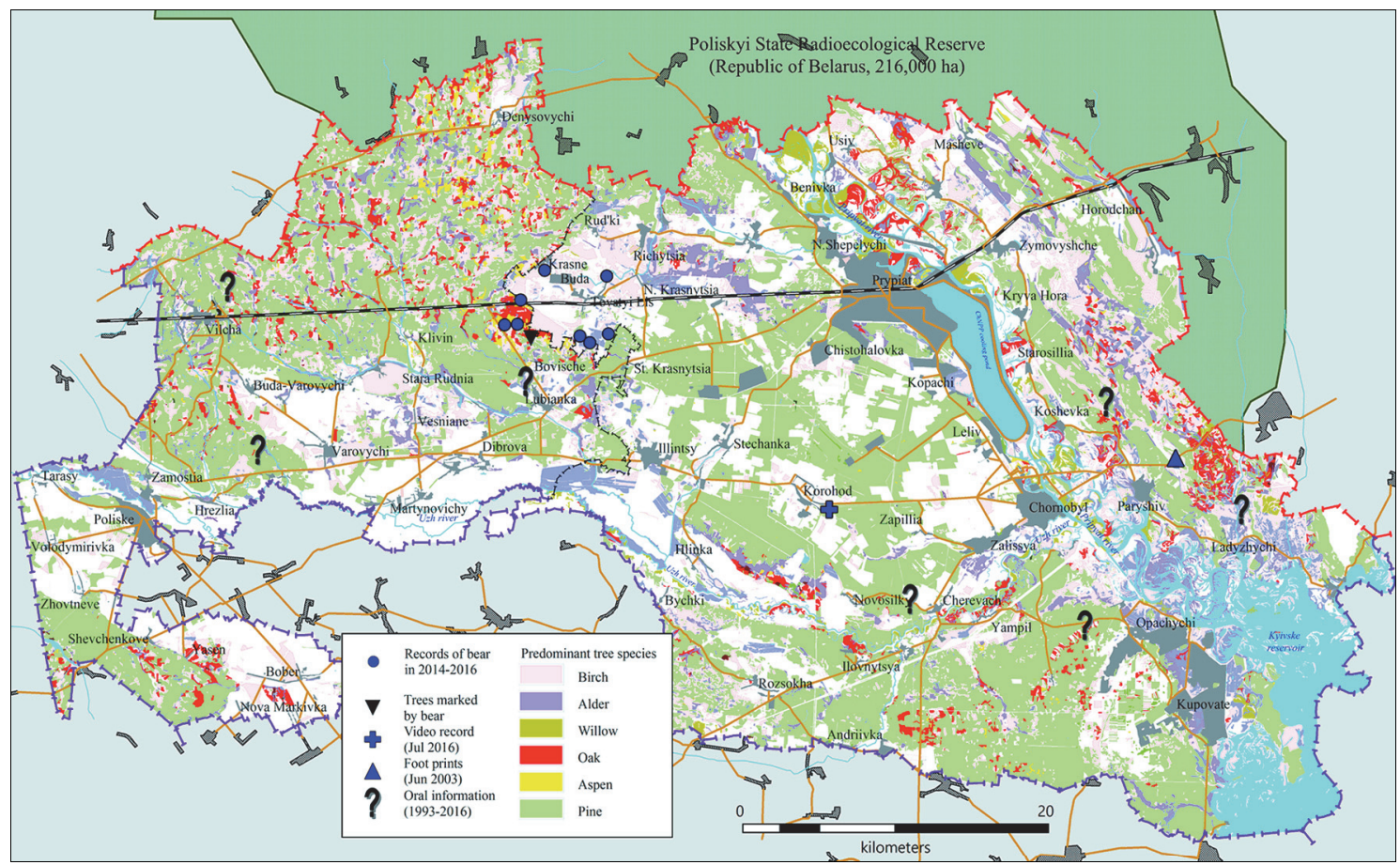

Fig. 6. Brown bear records in CEZ over 20-year period referring to pattern of woodland distribution (made on: Development project, 2006).

Рис. 6. Повідомлення про бурого ведмедя у зоні відчуження за 20-річний період відносно розподілу деревної рослинності (складено за: Проект організації, 2006).

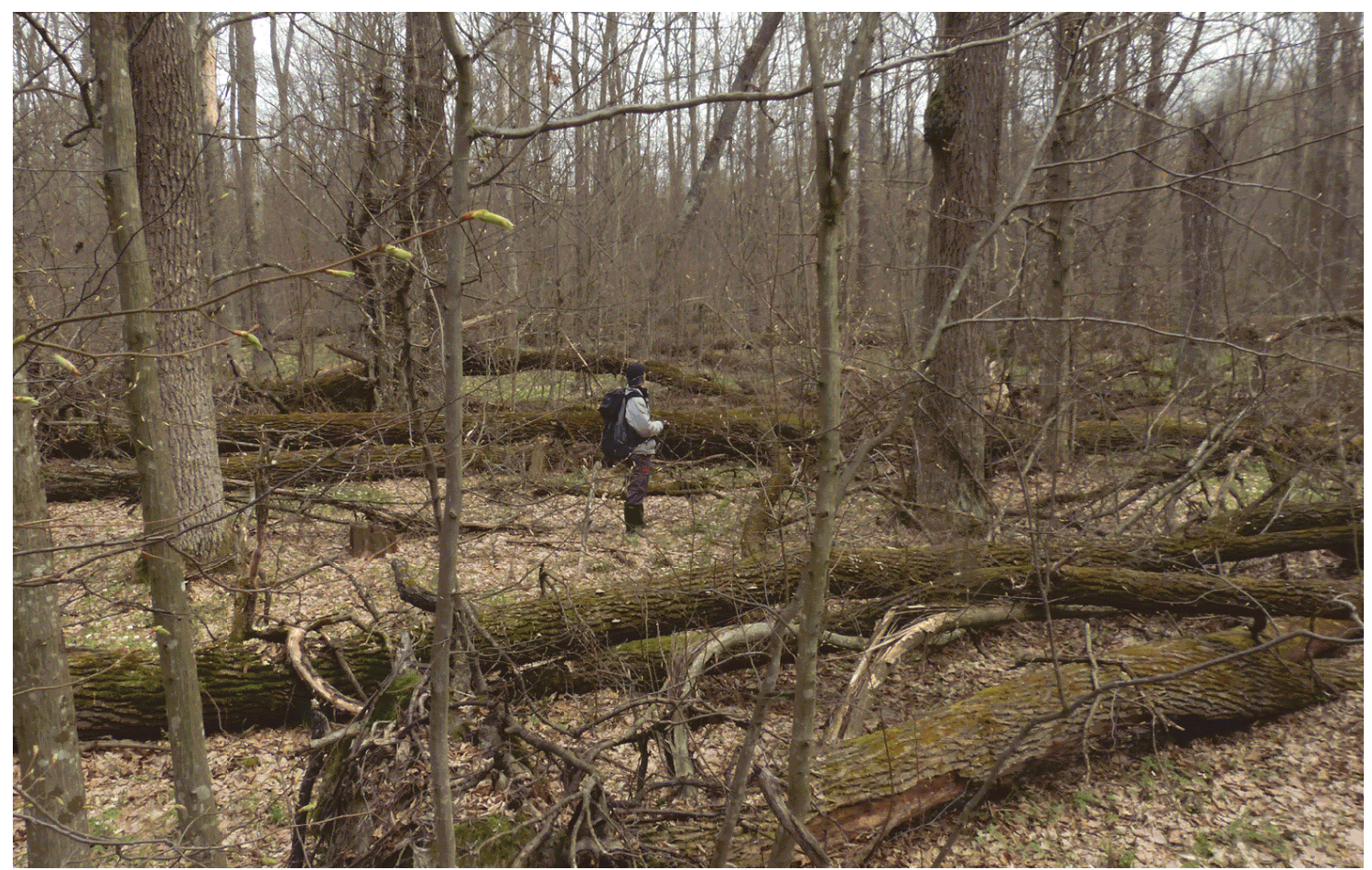

Fig. 7. Oak-hornbeam forest with fallen trees.

Рис. 7. Дубово-грабовий ліс з поваленими деревами. 


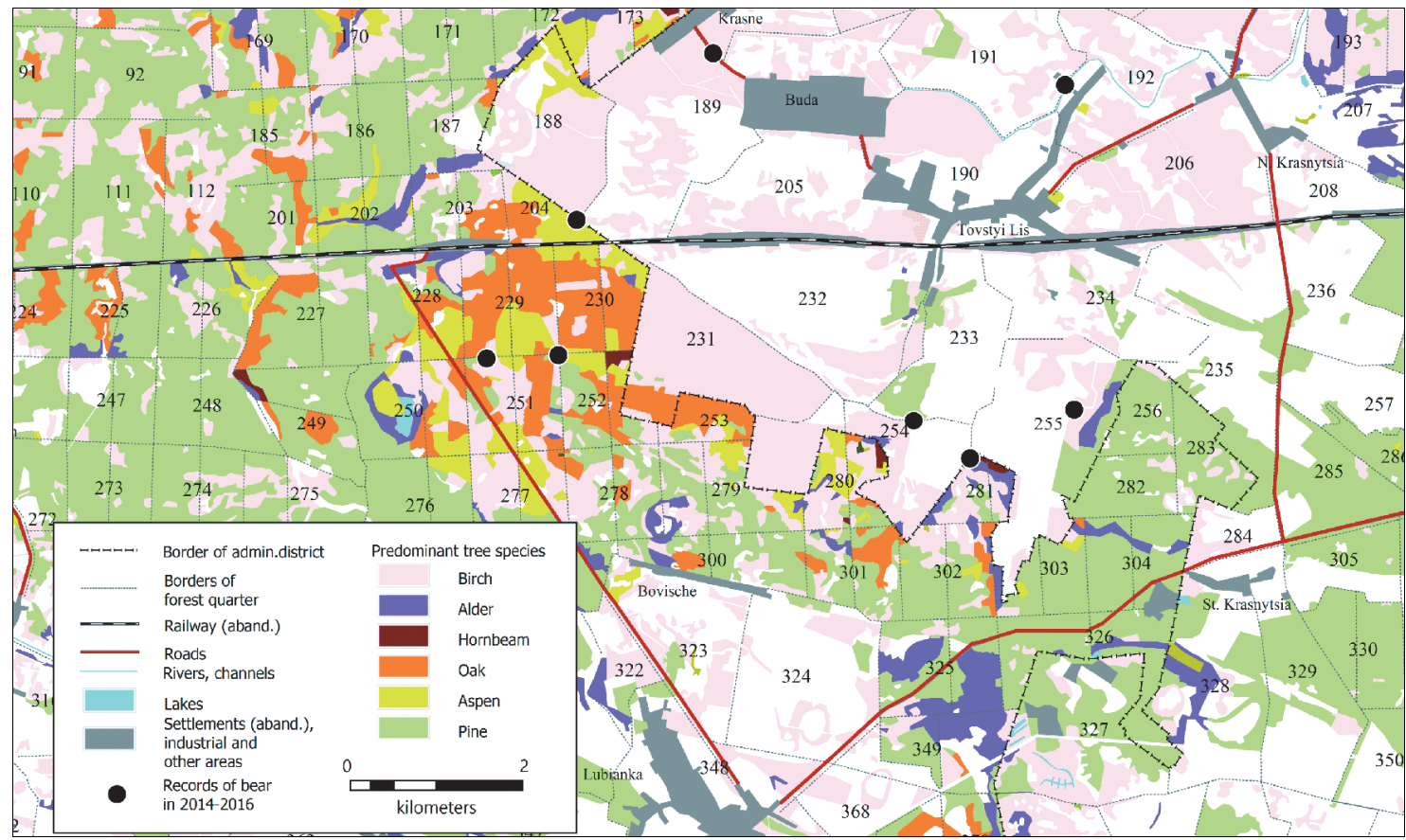

Fig. 8. Brown bear records near Tovsty Lis village. The woodland distribution pattern and forest quarters numbering are from: Development project (2006).

Рис. 8. Реєстрація бурого ведмедя біля с. Товстий ліс. Схема розподілу деревної рослинності і нумерація лісових кварталів складено за: Проектом організації (2006).

For example, the species density in the Ukrainian Carpathians varies between 0.3 and 1.5 animals/1,000 ha (Delehan et al., 2015); in the Tver region of Russia - 0.5-1.0 animals/1,000 ha (Pazhetnov, 1990); in the Vitebsk region of Belarus - up to 2.5 animals/1,000 ha (estimated by: Savitsky et al., 2005). Based on these observations $0.3-0.5$ animals $/ 1,000$ ha could be expected for the conditions of the CEZ. Even if we assume that this applies only to the most favourable habitats that cover a half of the CEZ, we can expect at least 50 animals living there in the future; and this may be two times higher as large if we include the Belarusian Reserve. Being a euryphagous animal that slumbers in winter, the bear has ecological advantages compared with other large carnivores, and therefore generally has a higher density than competitors (Pazhetnov, 1990).

The accumulated data suggest that a resident breeding group of brown bear is now present in both in the Ukrainian and Belarusian parts of the exclusion zone, after centuries of absence. There are insufficient data available to date to allow firm conclusions to be drawn regarding the number of individuals, their sex and age structure and their spatial distribution. However, there is no doubt that the CEZ is acting as a wildlife reserve for these bears, providing favourable conditions for the successful revival of this species in the Polissia.

\section{Acknowledgements}

The research described in this paper was carried out with the support of the Ministry of Ecology and Natural Resources of Ukraine (the project named "Research and identification of the exclusion zone areas with the most valuable natural systems and worthy of the highest conservation status, and their passporting") and under the TREE project (http://tree.ceh.ac.uk/) funded by the United Kingdom Natural Environment Research Council, Radioactive Waste Management Limited and the Environment Agency. The writing up of this study was funded by the EURATOM COMET project. The authors appreciate Sergii Paskevych for the assistance during field work, provision of oral data, discussions of the observations and access to his own footage. We also appreciate Igor Chyzhevskyi for the information support. The advice of Marina Shkvyria is also gratefully acknowledged. 


\section{References}

Гащзак, С. П. «Заповедные проблемы» Чернобыльской зоны // Заповідна справа в Україні. — 2006. — Том 12, № 2. - C. 83-90.

[Gashchak, S. P. "Reserved problems" of the Chornobyl zone // Reserve Management in Ukraine. — 2006. — Vol. 12, No. 2. - P. 83-90. (in Rus.)]

Гащчак, С. П., Вишневський, Д. О., Заліський, О. О. Фауна хребетних тварин Чорнобильської зони відчуження (Україна). - Славутич : Вид-во ЧЦПЯБРВР, 2006. — 100 с.

[Gashchak, S. P., Vyshnevsky, D. O., Zaliskyi, O. O. Vertebrate Fauna of the Chornobyl Exclusion Zone (Ukraine). - Slavutych : Publishing House of ChTsPYaBRVR, 2006. — 100 p. (in Ukr.)]

Гептнер, В. Г., Наумов, Н. П., Юргенсон, П. Б. и др. Млекопитающие Советского Союза. Морские коровы и хищные. - Москва : Высшая Школа, 1967. - Том 2, ч. 1. - 1004 с.

[Heptner, V. G., Naumov, N. P., Jurgenson, P. B. et al. Mammals of the Soviet Union. Sea cows and carnivores. - Moscow : Vysshaia Shkola, 1967. - Vol. 2, Part 1. - 1004 p. (in Rus.)]

Делеган, I. В., Башта, А.-Т. В., Скільський, І. В., Лущак, М. М. Дослідження ведмедя бурого на теренах України та суміжних територіях в історичному аспекті // Ведмідь бурий (Ursus arctos): проблеми збереження та дослідження популяції в Україні / За ред. І. В. Дикого, М. Г. Шквирі. - Київ : ТОВ «СІК ГРУП Україна», 2015. - C. 15-35.

[Delehan, I. V., Bashta, A.-T. V., Skilskyi, I. V., Lushchak, M. M. Investigation of the brown bear in the territory of Ukraine and on neighbouring areas in historical perspective // The brown bear (Ursus arctos): problems of preservation and research of population in Ukraine / Ed. by I. V. Dykyy, M. H. Shkvyria. — Kyiv : SIK GROUP UKRAINE LLC, 2015. — P. 15-35. (in Ukr.)]

Дерябина, Т. Г. Распространение и численность включенных в Красную книгу Республики Беларусь крупных млекопитающих (зубр, медведь, рысь, барсук) на территории Полесского государственного радиационно-экологического заповедника // Фаунистические исследования в Полесском государственном радиационно-экологическом заповеднике : Сб. науч. труд. / Под ред. Г. В. Анципова. — Гомель : РНИУП «Институт радиологии», 2008. - С. 19-35.

[Deriabina, T. G. Distribution and number of the large mammals (bison, bear, lynx, badger) included into the Red Book of Belarus Republic in the territory of Poliskyi State Radiation and Ecology Reserve // Faunal studies in Poliskyi State Radiation and Ecology Reserve: Proceedings / Ed. by G. V. Antsipov. - Homel : RNIUP "Institute of Radiology", 2008. — P. 19-35. (in Rus.)]

Дерябина, Т. Г. Зона отчуждения Чернобыльской АЭС - резерват охраняемых видов диких животных // Красная книга Республики Беларусь : состояние, проблемы, перспективы: материалы международной научной конференции, Витебск, 13-15 декабря 2011 г. / Вит. гос. ун-т ; редкол.: В. Я. Кузьменко (отв. ред.) и [и др.]. — Витебск : УО «ВГУ им. П. М. Машерова», 2011. — С. 43-45.

[Deriabina, T. G. The exclusion zone of Chornobyl NPP: reserve of protected wild animal species // The Red Book of Belarus Republic: status, problems, prospects. Proceedings of International Scientific Conference, Vitebsk, 13-15 December, $2011 /$ Vit. State Univ.; Editorial board: V. Ya. Kuzmenko (exec. ed.) [et al.]. — Vitebsk : UO "VGU im. P. M. Masherov", 2011. — P. 43-45. (in Rus.)]

Дикий, І. В., Шквиря, М. Г., Хоєцький, П. Б. Сучасний стан популяції ведмедя бурого в Україні: просторова структура і особливості екології, чисельність і методи дослідження // Ведмідь бурий (Ursus arctos): проблеми збереження та дослідження популяції в Україні / Наук. ред. І. В. Дикий, М. Г. Шквиря. - Київ : ТОВ «СІК Груп Україна», 2015. - С. 36-72.

[Dykyy, I. V., Shkvyria, M. H., Khoietskyi, P. B. Current status of the brown bear population in Ukraine: spatial structure and environmental features, quantity and research methods // In monograph: The brown bear (Ursus arctos): problems of preservation and investigation of its population in Ukraine / Ed. by I. V. Dykyy, M. H. Shkvyria. - Kyiv : SIK Group Ukraine LLC, 2015. - P. 36-72. (in Ukr.)]

Жила, С. М. Бурий ведмідь (Ursus arctos L.) в Українському Поліссі // Вестник зоологии. — 1997. — Tом 31 , № 3. - C. 77.

[Zhyla, S. M. The brown bear (Ursus arctos L.) in Ukrainian Polissia // Vestnik zoology. — 1997. — Vol. 31, No. 3. — P. 77. (in Ukr.)]

Кириков, С. В. Изменения животного мира в природных зонах СССР (XIII-XIX вв.): Лесная зона и лесотундра. - Москва : Изд-во АН СССР, 1960. - 158 с.

[Kirikov, S. V. Changes of Fauna in Natural Areas of the USSR (in the $13^{\text {th }}-19^{\text {th }}$ centuries.): Forestlands and Forest Tundra. Moscow : Publishing House of the USSR Academy of Sciences, 1960. — 158 p. (in Rus.)]

Кириков, С. В. Человек и природа восточноевропейской лесостепи в X - начале XIX в. - Москва : Наука, 1979. - $184 \mathrm{c}$.

[Kirikov, S. V. Man and nature in the Eastern European forest steppe in the $10^{\text {th }}$ to early $19^{\text {th }}$ centuries. - Moscow : Nauka, 1979. - 184 p. (in Rus.)]

Крижанівський, В. І. Стан популяцій мисливських видів ссавців / Розбудова екомережі України. - Київ : UNDP, Проект Екомережі, 1999. - С. 89-91.

[Kryzhanivskyi, V. I. Status of populations of game mammals species / Development of Ecological Network in Ukraine. Kyiv : UNDP, Ecological Network Project, 1999. — P. 89-91. (in Ukr.)]

Пажетнов, В. С. Бурый медведь. - Москва : ВО «Агропромиздат», 1990. - 215 с. [Pazhetnov, V. S. The brown Bear. — Moscow : VO “Agropromizdat”, 1990. — 215 p. (in Rus.)] 
Петров, М. Ф. Ботаніко-географічні дослідження Чорнобильської зони // Проблеми Чорнобильської зони відчуження. - 2016. - Вип. 15-16. - С. 52-263.

[Petrov, M. F. Botanical and geographical research of the Chornobyl zone // Problems of the Chornobyl exclusion zone. 2016. - Iss. 15-16. - P. 52-263. (in Ukr.)]

Петров, М. Ф., Гащзак, С. П. Радіоекологічні, ландшафтні та геоботанічні умови ділянки «Товстий ліс» як передумови надання їй охоронного статусу // Проблемы Чернобыльской зоны отчуждения. — 2013. — Вып. 11. - C. 102-128.

[Petrov, M. F., Gashchak, S. P. Radioecological, landscape and geobotanical conditions of Tovstyi Lis site as preconditions for its reserved status // Problems of the Chornobyl Exclusion Zone. — 2013. — Iss. 11. — P. 102-128. (in Ukr.)]

Погребняк, П. С. Основы лесной типологии. - Киев : Изд-во АН УССР, 1955. - 456 с.

[Pohrebniak, P. S. Basis of Forest Typology. - Kyiv : Publishing House of Academy of Science of USSR, 1955. - 456 p. (in Rus.)]

Проект організації і розвитку лісового господарства державного спеціалізованого комплексного підприємства «Чорнобильська пуща» Державного департаменту-адміністрації зони відчуження і зони безумовного (обов'язкового) відселення / Українське державне проектне лісовпорядне виробниче об'єднання. Комплексна експедиція. - Ірпінь, 2006.

[Development project for the forestry of the state specialized integrated enterprise "Chornobyl Puscha" under the State department-administration of the exclusion zone and zone of absolute (mandatory) resettlement / Ukrainian state engineering forest management production association. Integrated expedition. — Irpin, 2006. (in Ukr.)]

Савицкий, Б. П., Кучмель, С. В., Бурко, Л. Д. Млекопитающие Беларуси / Под ред. Б. П. Савицкого. - Минск : Изд. Центр БГУ, 2005. - 319 с.

[Savitsky, B. P., Kuchmel, S. V., Burko, L. D. The Mammals of Belarus / Ed. by B. P. Savitsky. — Minsk : Publ. Centre of BSU, 2005. - 319 p. (in Rus.)]

Ситникова, E. Ф. Хищные млекопитающие биосферного заповедника «Брянский Лес» (Россия, Брянская область) // Ученые записки Таврического национального университета им. В. И. Вернадского. Серия Биология, химия. - 2004. - Том 17 (56), № 2. - 144-150.

[Sitnikova, E. F. The carnivore of Biosphere Reserve "Briansk Forest" (Russia, Briansk region) // Proceedings of V. I. Vernadsky Tavria National University. Series Biology, Chemistry. - 2004. - Vol. 17 (56), No. 2. - P. 144-150. (in Rus.)]

Сокур, I. T. Історичні зміни та використання фауни ссавців України. - Київ : Вид-во АН УРСР, 1961. - 84 с. [Sokur, I. T. Historical Changes and Use of Mammals Fauna in Ukraine. - Kyiv : Publ. House of USSR AS, 1961. — 84 p. (in Ukr.)]

Червона книга Украӥни. Тваринний світ / За ред. І. А. Акімова. - Київ : Глобалконсалтинг, 2009. — 600 с. [The Red Data Book of Ukraine. Wildlife / Ed. by I. A. Akimov. — Kyiv : Hlobalkonsaltynh, 2009. — 600 p. (in Ukr.).

Ткачук, Ю. Б. Деякі матеріали до екології ведмедя на Буковині // Вестник зоологии. — 2000. — Том 34, № 12. - C. 74 .

[Tkachuk, Yu. B. Some materials on bear ecology in Bukovina // Vestnik zoology. — 2000. — Vol. 34, No. 1-2. — P. 74. (in Ukr.)]

Chapron, G., Kaczensky, P., Linnell, J. D. C. et al. Recovery of large carnivores in Europe's modern human-dominated landscapes // Science. - 2004. - Vol. 346, Iss. 6216. — P. 1517-1519. — DOI: 10.1126/science. 1257553 .

Shkvyria, M., Vishnevsky, D. Large carnivores of the Chornobyl NPP exclusion zone // Vestnik zoologii. — 2012. Vol. 46, No. 3. - P. 239-246. 